\title{
Towards a single retail banking market? : new evidence from euroland
}

Citation for published version (APA):

Kleimeier, S., \& Sander, H. (2001). Towards a single retail banking market? : new evidence from euroland. METEOR, Maastricht University School of Business and Economics. METEOR Research Memorandum No. 062 https://doi.org/10.26481/umamet.2001062

Document status and date:

Published: 01/01/2001

DOI:

10.26481/umamet.2001062

Document Version:

Publisher's PDF, also known as Version of record

\section{Please check the document version of this publication:}

- A submitted manuscript is the version of the article upon submission and before peer-review. There can be important differences between the submitted version and the official published version of record.

People interested in the research are advised to contact the author for the final version of the publication, or visit the DOI to the publisher's website.

- The final author version and the galley proof are versions of the publication after peer review.

- The final published version features the final layout of the paper including the volume, issue and page numbers.

Link to publication

\footnotetext{
General rights rights.

- You may freely distribute the URL identifying the publication in the public portal. please follow below link for the End User Agreement:

www.umlib.nl/taverne-license

Take down policy

If you believe that this document breaches copyright please contact us at:

repository@maastrichtuniversity.nl

providing details and we will investigate your claim.
}

Copyright and moral rights for the publications made accessible in the public portal are retained by the authors and/or other copyright owners and it is a condition of accessing publications that users recognise and abide by the legal requirements associated with these

- Users may download and print one copy of any publication from the public portal for the purpose of private study or research.

- You may not further distribute the material or use it for any profit-making activity or commercial gain

If the publication is distributed under the terms of Article $25 \mathrm{fa}$ of the Dutch Copyright Act, indicated by the "Taverne" license above, 
Version: August 2001

\title{
Towards a Single Retail Banking Market? New Evidence from Euroland
}

\author{
by \\ Harald Sander* and Stefanie Kleimeier
}

\begin{abstract}
Executive Summary:
Our study reviews the process towards creating a single European retail banking market. The EU has aimed at integrating the traditionally heterogeneous banking market in Europe by means of harmonizing legislation. While the wholesale banking market integration is considered to be more advanced, retail banking integration is still in its infancy. Cross-border lending, cross-border mergers, and the promises of new technologies have not yet delivered the creation of a single retail banking market. In this paper we provide new evidence on this issue. In particular, we find that there are some tendencies for a more integrated corporate lending market, while consumer lending markets are still remaining more fragmented. We identify three reasons for a lack of integration: A lack of international arbitrage, a limited pass-through of interest rate changes onto lending rates, and a limited national and international competitive retail banking environment. The results also suggest that the introduction of the single currency may have already made a positive impact on retail banking market integration.
\end{abstract}

Harald Sander is with the University of Applied Sciences in Cologne, Germany. Stefanie Kleimeier is with the Universiteit Maastricht, The Netherlands.

* corresponding author:

University of Applied Sciences Cologne

Claudiusstrasse 1

50678 Cologne

Germany

e-mail: gh.sander@t-online.de

phone: +49-221-82753419

fax: $+49-221-82753131$ 


\section{Introduction}

An integrated market for financial services is been considered an essential part of the European Union's (EU) single market project. In the wording of a recent communication from the EU Commission to the council and the European parliament it reads: "The Lisbon European councils deadline of 2005 to establish an integrated European market in financial services is central to the community's employment and growth agenda." This is especially true since finance in Europe is traditionally bank dominated. While the creation of a single wholesale banking market is generally considered to be more advanced, integration in retail banking is often perceived to be lacking behind in particular since lending and borrowing activities take place mostly within a narrow geographic region. One reason for these localized retail banking markets where banks are neither reaching out for all prospective Euroland customers, nor are consumers shopping around for credits in the whole Euroland is given by Padoa-Schioppa (2000), who argues that "proximity is an intrinsic characteristic of the retail market with or without the emergence of a currency embracing a wider area".

Our study contributes to this discussion and provides new evidence on the state and development of integration of European retail banking markets. In section 2, we discuss the major trends in European banking regulation and market developments. In section 3, we provide new evidence on the emergence of a single Euroland retail banking market. In particular we investigate the current state of integration for three different credit instruments across ten Euroland countries between 1995 and 2000. Section 4 concludes by pointing to the continuously important role of competition policy 
and the special role of the single currency in the process of integrating European retail banking markets.

\section{Structure and trends in European banking market integration}

\subsection{European banking: From heterogeneity to the single market project}

The national differences in European banking, which the EU is trying to overcome have their roots in the late $19^{\text {th }}$ century. The European banking system developed historically from the unit-based banking system of the $17^{\text {th }}$ and $18^{\text {th }}$ century to the early $19^{\text {th }}$ century bi-polar system consisting of town-based banks financing domestic and international trade and country-based banks financing the local, predominantly agricultural economy. The change towards a more diverse banking system consisting of savings banks, building societies, cooperatives, joint-stock town-based banks, and country banks was brought about at the end of the $19^{\text {th }}$ century by the industrial revolution. With the increased importance of town-based banks, financial centres such as London or Paris developed. Parallel, the first branch systems developed so that by the end of the century most European countries had a nationwide branch system created by the large, joint-stock banks. In each country, the competition between country-based (regional) banks and town-based (national) banks took a different form and led to heterogeneity in European banking. Furthermore, the relationship between industry and banks shaped the market. Whereas in the UK, banks focussed more on financing trade and less on financing industry, the ties between industry and banks were much closer in continental Europe. Consequently, UK industrial firms looked to the financial markets for funding (see Molyneux, 1996). With the growing importance of industry over trade, the UK financial system developed to be more market oriented whereas the continental European system became mainly 
bank oriented. In general, however, bank lending plays a dominant role in providing funds to the corporate, private, and public sector in the whole of Europe.

Based on data for 1999 provided by the European Central Bank (ECB) (2000a) (see Table 1), in the Euroland bank loans amounted to a larger percentage of the gross domestic product (GDP) than in the US or Japanese system. In contrast, market based forms of funding which are an alternative for corporations are used to a lesser extend in the Euroland.

Table 1: Euro-Area Characteristics in June 1999 (in percent of GDP)

\begin{tabular}{lrrr}
\hline & Euro Area & USA & Japan \\
\hline Bank Loans & 100.4 & 48.4 & 107.0 \\
Outstanding domestic debt securities & 88.8 & 164.6 & 126.5 \\
- issues by corporates & 3.3 & 29.0 & 14.6 \\
- issued by financial institutions & 31.0 & 45.4 & 18.8 \\
- issued by the public sector & 54.5 & 90.2 & 93.1 \\
Stock Market Capitalization & 71.1 & 163.3 & 137.7 \\
\hline
\end{tabular}

Source: ECB Monthly Bulletin, January 2000.

Note: All data are for June 1999 except for stock market capitalization, which are for October 1999.

The EU is striving to overcome the heterogeneity in European banking in order to create a single market for financial services. Reviewing the regulatory process towards financial integration in Europe reveals that even if the establishment of the common market has been an objective in the EU since the 1957 Treaty of Rome and has been reinforced by the 1985 White Paper and the 1986 Single European Act, very little had been achieved even on a regulatory level until the $2^{\text {nd }}$ BD of 1989. Regarding key regulatory elements, the First Banking Directive $\left(1^{\text {st }}\right.$ BD) of 1977 which allowed for cross border branching under the host country rule ${ }^{1}$ was not very effective in reducing differences between national regulatory systems and was thus followed by a $2^{\text {nd }} \mathrm{BD}$. This $2^{\text {nd }} \mathrm{BD}$ relied on three fundamental principles of harmonisation, mutual recognition, and 
home country control and supervision ${ }^{2}$ - the latter representing a complete turnaround in regulatory policy compared to the $1^{\text {st }}$ BD. Since 1986 , additional directives which are aimed at further harmonization of the different national EU banking markets have been passed concerning bank supervision, capital adequacy, solvency standards, money laundering, consumer credit, or publishing and consolidation of annual accounts to name but a few ${ }^{3}$. In the area of consumer credit, in 1986 the European Community introduced a consumer credit directive. The main two objectives of this directive were consumer protection and facilitation of cross-border credit by means of harmonisation of the banks' information provision to its customers. This directive was amended and completed by two more consumer credit directives in 1990 and 1998, respectively ${ }^{4}$. Following more than a decade of designing and implementing financial market legislation, the EU has now adopted a Financial Services Action Plan with the explicit objective to "devise a strategy for improving the operation of the single market in financial services, based on effective application of current legislation and amendment of the legislation where it is ineffective or incomplete" (Commission Of the European Union, 1998). On January 1, 1999, the Euro replaced the national currencies of Austria, Belgium, Finland, France, Germany, Ireland, Italy, Luxembourg, the Netherlands, Portugal, and Spain. Of the remaining EU countries, Greece initially failed to meet the required economic criteria but joined EMU on January 1, 2001, whereas Denmark, Sweden, and the United Kingdom decided not join the EMU as yet.

\footnotetext{
${ }^{1}$ Under the host country rule a bank had to obtain permission to operate in a foreign country by the supervisory agencies of that country.

${ }^{2}$ Harmonisation should lead to a system where banks operating in several countries face a common set of EU regulations. Mutual recognition implies that the banking charter of the home country is sufficient to operate in all EU countries. Home country rule, finally, stipulates that foreign owned banks are regulated by their home country and not by the host country.

${ }^{3}$ For details see Kleimeier (2001), Sander and Kleimeier (2000), Diez Guardia (2000), Zimmerman (1995).

${ }^{4}$ For details and evaluation see Diez Guardia (2000).
} 


\subsection{Integration as a market-driven process}

Assessing the Euroland banking markets, integration can be considered as far advanced from a purely legal perspective (Zimmerman 1995, Bredemeier 1995). However, many observers find that such a single market is not yet fully present in all areas of financial services. Whereas Euroland interbank and wholesale markets are considered to be more integrated, the extent of integration in the retail banking markets is often being questioned. For example, the Commission of the European Union (1999) states that “the Union's financial markets remain segmented and business and consumers continue to be deprived of direct access to cross-border financial institutions." Following this line of reasoning, for regulation to become effective the market should react to these legal developments. The major driving forces for integrating retail banking are cross-border lending and cross-border mergers and acquisitions (M\&As). Moreover and more recently, information technology (IT) is often said to have the potential to create a single market. The impact of these three developments on retail market integration will be discussed briefly in the following sections.

\section{Cross border lending}

At present, the focus in bank lending and deposit taking is clearly domestic. As data reported by the ECB (2000b) shows that in 199979.8 per cent of all loans were domestic. This figure increases even to 91.2 per cent when considering only loans to the non-bank private sector. Regarding deposits, 72.8 per cent of all deposits and 86.5 per cent of deposits to the non-bank private sector were domestic. However, the growth rates for all Euroland activities - with the exception of deposits from the non-bank private sector - are positive and larger than the corresponding growth rates for domestic activities. Furthermore, the market shares of foreign 
banks in Europe are still very low as Table 2 shows. Whereas in most countries the market share of European banks is higher than that of third country banks, the size of the market share is still very low for most countries. On an overall average, the market share of foreign banks originating from the (at that time) European Economic Area (EEA) countries amounts to only 3.4 percent of the total assets of domestic banks in 1997. With the exception of Belgium, Ireland and Luxembourg, the market share of foreign EEA banks is less than $10 \%$.

Table 2: Market Share of Foreign Banks as Percentage of the Total Assets of Domestic Banks (end 1997)

\begin{tabular}{|c|c|c|c|c|c|}
\hline \multirow[t]{2}{*}{ Country } & \multicolumn{2}{|c|}{ From EEA Countries } & \multicolumn{2}{|c|}{ From Third Countries } & \multirow[t]{2}{*}{ Total } \\
\hline & Branches & Subsidiaries & Branches & Subsidiaries & \\
\hline Belgium & 9.0 & 19.2 & 6.9 & 1.2 & 36.3 \\
\hline Germany & 0.9 & 1.4 & 0.7 & 1.2 & 4.3 \\
\hline Spain & 4.8 & 3.4 & 1.6 & 1.9 & 11.7 \\
\hline France $^{1}$ & 2.5 & & 2.7 & & 9.8 \\
\hline Ireland & 17.7 & 27.8 & 1.2 & 6.9 & 53.6 \\
\hline Italy & 3.6 & 1.7 & 1.4 & 0.1 & 6.8 \\
\hline Luxembourg & 19.4 & 65.7 & 1.4 & 8.1 & 94.6 \\
\hline Netherlands & 2.3 & 3.0 & 0.5 & 1.9 & 7.7 \\
\hline Austria & 0.7 & 1.6 & 0.1 & 1.0 & 3.3 \\
\hline Portugal & 2.5 & 6.8 & 0.1 & 1.0 & 10.5 \\
\hline Finland & 7.1 & 0.0 & 0.0 & 0.0 & 7.1 \\
\hline Euroland weighted average & 3.4 & & 1.6 & & 12.7 \\
\hline
\end{tabular}

Source: Belaisch et.al. (2001), Table 10. Blanks indicate missing values. ${ }^{1}$ Data for 1996.

The evidence in table 2 does not allow the conclusion that a truly Europe-wide banking system has emerged yet. In that case one would expect higher and more uniform market shares.

\section{Cross border mergers}

The EU regulatory process sparked two phases of bank M\&As in Europe: The first phase took place in the late 1980 s and early 1990 s in reaction to the $2^{\text {nd }} \mathrm{BD}$ and the second phase took place in the second half of the 1990s in anticipation of the EMU (Tourani Rad and van Beek, 1999). Reviewing the evidence on M\&As in European banking reveals that M\&As predominantly take 
place within national borders and within the same type (see Table A1 and Table 3). From Table 3 note first that the total value of domestic M\&As exceeds that of cross-border M\&As, mainly driven by acquisitions of commercial banks and securities firms. Only for insurance companies the value of cross-border M\&As exceed the value of domestic M\&As. This implies that consolidation is still taking place on a national rather than international level. Furthermore, for commercial banks and securities firms M\&As within Europe are as important as other foreign M\&As, indicating a global rather than regional consolidation process. Second, consolidation within the sector is more common than consolidation across sectors - with domestic M\&As and to a lesser extend Europe-Non-Europe M\&As when the acquirer is a securities firm being the only exceptions ${ }^{5}$. Furthermore, Belaisch et.al (2001) argue that the speed of M\&As, it seems however, that the speed has increased in recent years for large banks, as the majority of the 30 largest Euroland banks listed in Table A1 are the result of a merger. As an alternative to crossborder M\&As which can be difficult - for example due to a government's interest in limited foreign ownership in key institutions or to create 'national champions' - alliances have been favoured as Table A2 shows. In addition, M\&As between smaller banks has been continuously ongoing for several years and resulted in an overall decrease of the number of banks per country. Examples can be found when looking at the numbers of German savings banks and credit cooperatives, which fell by 5 and 13 percent, respectively, between 1995 and 2000. Taken together these findings show that the typical EU bank can still be characterised as a domestic bank.

\footnotetext{
${ }^{5}$ It is interesting to note that the only strategy which can be characterised as clearly European is the acquisition strategy that insurance company follow within Europe when acquiring banks. This strategy amounts to $13.4 \%$ of all Intra-European M\&As and is the only M\&As type for which the intra-European percentage is higher than either the domestic or the non-Europe share. Thus, it appears that a European trend towards ALLFINANZ might be emerging.
} 


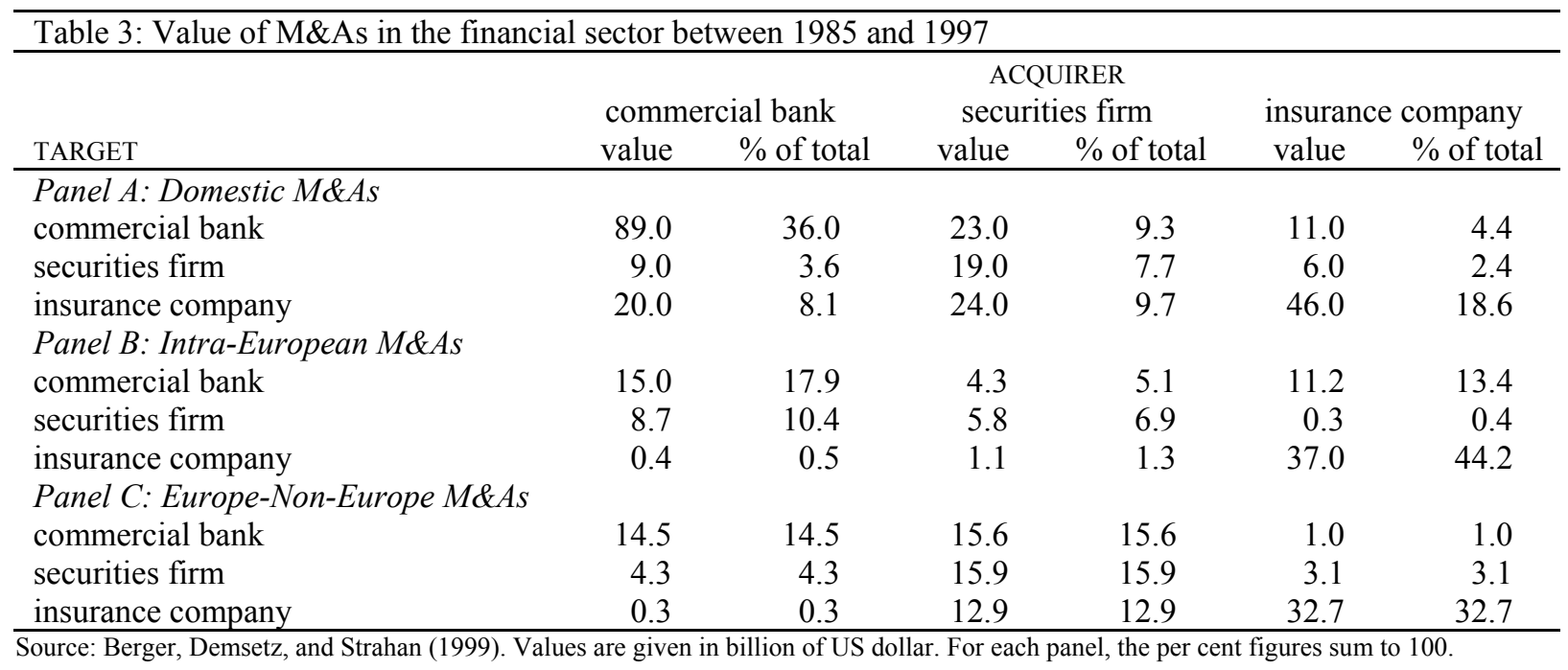

\section{The potential impact of IT}

IT has influenced all areas of banking through an internal as well as an external channel. In particular its external application, which shapes the way in which customers access a bank's services. Here, traditional branch banking is slowly - though not fully - being replaced by remote banking via automated teller machines (ATM), electronic money, telephone banking, online security trading, or internet banking. The crucial issue is to what extend remote banking has a potential to promote retail financial market integration. As stated recently in the EU Commission's Financial Services Action Plan "E-Commerce is already revolutionizing retailing and distribution of many financial services. Suppliers - EU and non-EU - will be able to make contact with potential users across national boundaries at minimal distribution cost. Users will benefit from a wider range of innovative products. The overall impact will be to reinforce and cement market integration." 
As Table 4 reveals, the extent to which remote banking is implemented differs across Europe. ATMs and telephone banking are the most widely developed remote banking services, with an average growth rate of 50\% between 1993 and 1997. Access to telephone banking is still limited and ranges from below 5\% in Finland, Italy, and Sweden to $10 \%$ in France and the United Kingdom. Telephone banking has also been increasing during the 1990s but might be replaced by internet banking. The density and growth of 'electronic funds transfer at the point of sale' (EFTPOS) illustrates the use of electronic payment instruments. Exceptionally high growth rates can be observed here but the difference between European countries is still quite pronounced. It appears that at the end of the 1990s cash still plays an important role but is used for smaller and more spontaneous payments whereas electronic payments are used for larger and more regular transactions (ECB 1999c).

Table 4: Selected remote banking services across Europe

\begin{tabular}{|c|c|c|c|c|c|c|c|}
\hline \multirow[t]{2}{*}{ country } & \multirow[t]{2}{*}{$\begin{array}{l}\text { telephone } \\
\text { banking }^{1}\end{array}$} & \multicolumn{2}{|c|}{ ATM machines } & \multicolumn{2}{|c|}{ EFTPOS terminals } & \multicolumn{2}{|c|}{$\begin{array}{c}\text { electronic money in } \\
1997\end{array}$} \\
\hline & & $\begin{array}{l}\text { number in } \\
1997^{2}\end{array}$ & $\begin{array}{l}\text { change } \\
1993-97\end{array}$ & $\begin{array}{c}\text { number in } \\
1997^{2}\end{array}$ & $\begin{array}{l}\text { change } \\
1993-97\end{array}$ & $\begin{array}{l}\text { number of } \\
\text { cards }^{3}\end{array}$ & $\begin{array}{c}\text { number of } \\
\text { loading } \\
\text { machines }\end{array}$ \\
\hline Austria & n.a. & 533 & $+67 \%$ & 1,652 & $+621 \%$ & 3,400 & 3,495 \\
\hline Belgium & $5 \%$ & 492 & $+76 \%$ & 6,284 & $+48 \%$ & 3,430 & 6,438 \\
\hline Denmark & n.a. & 253 & $+134 \%$ & 11,923 & $+184 \%$ & n.a. & 3 \\
\hline Finland & $2 \%$ & 445 & $-25 \%$ & 10,506 & $+27 \%$ & 189 & 2,100 \\
\hline France & $10 \%$ & 462 & $+42 \%$ & 9,555 & $+4 \%$ & n.a. & n.a. \\
\hline Germany & $6 \%$ & 504 & $+64 \%$ & 1,984 & $+475 \%$ & 35,000 & 20,000 \\
\hline Greece & n.a. & 209 & $+155 \%$ & 2,831 & $+1,075 \%$ & 0 & 0 \\
\hline Ireland & $5 \%$ & 286 & $+30 \%$ & 1,402 & n.a. $\%$ & 0 & 0 \\
\hline Italy & $3 \%$ & 444 & +69\% & 4,896 & $+268 \%$ & 62 & 945 \\
\hline Luxembourg & n.a. & 613 & $+109 \%$ & 11,071 & $+32 \%$ & 0 & 0 \\
\hline Netherlands & $5 \%$ & 410 & $+41 \%$ & 7,715 & $+381 \%$ & n.a. & n.a. \\
\hline Portugal & n.a. & 631 & $+123 \%$ & 6,022 & $+116 \%$ & 384 & 5,129 \\
\hline Spain & $6 \%$ & 863 & $+55 \%$ & 16,691 & $+101 \%$ & 3,502 & 10,942 \\
\hline Sweden & $4 \%$ & 268 & $+5 \%$ & 7,778 & $+155 \%$ & n.a. & n.a. \\
\hline United Kingdom & $10 \%$ & 393 & $+20 \%$ & 8,984 & $+94 \%$ & 113 & 1,295 \\
\hline
\end{tabular}


Cost considerations and competitiveness have been the main motivators for banks to introduce IT as cost reductions of 60 to 70 per cent can be achieved by ATMs and EFTPOS or 75 to 99 per cent by internet banking when compared to branch banking. IT influences the competitive position of banks as it allows for price reductions due to falling cost, faster response time to customer requests, more tailor-made bank services based on readily available customer information, and access to new markets due to the deterioration of geographic restrictions that were present in branch banking but less so in remote banking (ECB 1999a, 1999b). However, the advances in IT have not yet led to any significant integration of retail markets. One reason might be the still high cost of cross-border money transfer which prevents retail customers from using a foreign bank's service even if it is accessible on-line. Furthermore, the Commission's (1999) Action Plan clearly outlined that uncertainties remain in the areas of marketing rules for financial products, information and transparency regarding contractual characteristics including redress procedures. Thus, whereas the potential for IT to enhance the integration of financial markets in Europe is clearly given, many obstacles still have to be eliminated. Realizing this need, the EU is currently discussing proposals for an E-Commerce Directive and a Distance Selling Directive.

\section{New evidence on the emergence of a single Euroland retail banking market}

Despite the regulatory efforts for creating an integrated Euroland banking market the market reaction in terms of cross-border lending and cross-border mergers has been limited so far and IT has not yet developed to its full potential. Nevertheless, at a first glance lending rates across Euroland appear today to be more similar than in the past. As discussed in the following, looking simply at interest rate convergence may be misleading when judging credit market integration. 
We therefore propose a different methodology. With this methodology we empirically investigate the current state of integration for 3 different credit instruments across 10 Euroland countries and over two different time periods. Based on this analysis, we are able to confirm the limited extend of the integration process so far. However, we also find that the introduction of the single currency is already showing an impact on lending market integration in particular with respect to corporate lending, pointing to the important role of a competitive environment in banking.

\subsection{Convergence of interest rates?}

In 1988 the Commission of the European Communities commissioned a study, now widely known as the Cecchini report (Commission of the European Communities, 1988), which derived quantitative estimates of the benefits of financial market integration. The study predicted that postintegration prices will fall to a level equal to the prices of the country with the lowest pre-integration prices. The Cecchini study advances the hypothesis of price equalization for financial assets within Europe as the characteristic of completely integrated markets. This "law of one price" manifests itself in financial markets as the "interest rate parity". From the point of view of the Cecchini study convergence of interest rates would reflect the emergence of a single retail banking market in Euroland. In a recent study (Kleimeier and Sander, 2001) carried out for the European Credit Research Institute (ECRI) of the Centre for European Policy Study (CEPS) we have investigated the development of three key retail interest rates in the Euroland: mortgage loans to households (N2), consumer loans to households (N3), and the lending rate charged to the corporate sector (N4). The data source is the ECB's National Retail Interest Rates Statistics $(\mathrm{N} 2, \mathrm{~N} 3$, and N4 refer to the number of the series as reported by the ECB). The rates are 
available on a monthly basis starting in the 1980s with most countries reporting regularly as off 1989. We concentrate here, however, to report for the period from April 1995 to December 2000 as for this time data for all countries are available on a regular base and because this is indeed the phase when the emergence of a single retail banking market is expected.

Figure 1 and 2 show the evolution of all three reported interest rates in both, nominal and real terms since 1995. A first observation is that all nominal rates are now closer together then they were in the mid-1990s. This convergence can, however, largely be attributed to the effect of macroeconomic factors, in particular the single monetary policy. When policy-determined interest rates and - consequently - short-term money market rates are converging, lending rates should also align more closely. This in itself is thus not yet a sign of an integrated lending market. Secondly, mortgage rates are now closer together than other lending rates. For example, while Italy had the highest average mortgage rate of $11.1 \%$ in the pre-EMU phase and Belgium with $6.1 \%$ the lowest rate, both countries have in the EMU phase an almost identical average rate of about $6 \%$. This is not so surprising since the credit characteristics of mortgages across countries are more similar throughout Euroland than lending rates charged for the other credit forms, which differ more widely in their underlying characteristics (as well as in their statistical definition). Thirdly, and more surprisingly, the real, consumer price inflation-corrected cost of mortgage borrowing still differs widely throughout the Euroland, with the highest real cost in France $(5.2 \%)$ and the lowest in Ireland (1.4\%). In a way one can say that the effectiveness of the convergence process for nominal mortgage rate leaves the consumer with diverging real cost of (mortgage) borrowing across Euroland. The reasons are, of course, the differences in consumer 
Figure 1: Nominal Interest Rates

Panel A: Mortgage Lending Rates
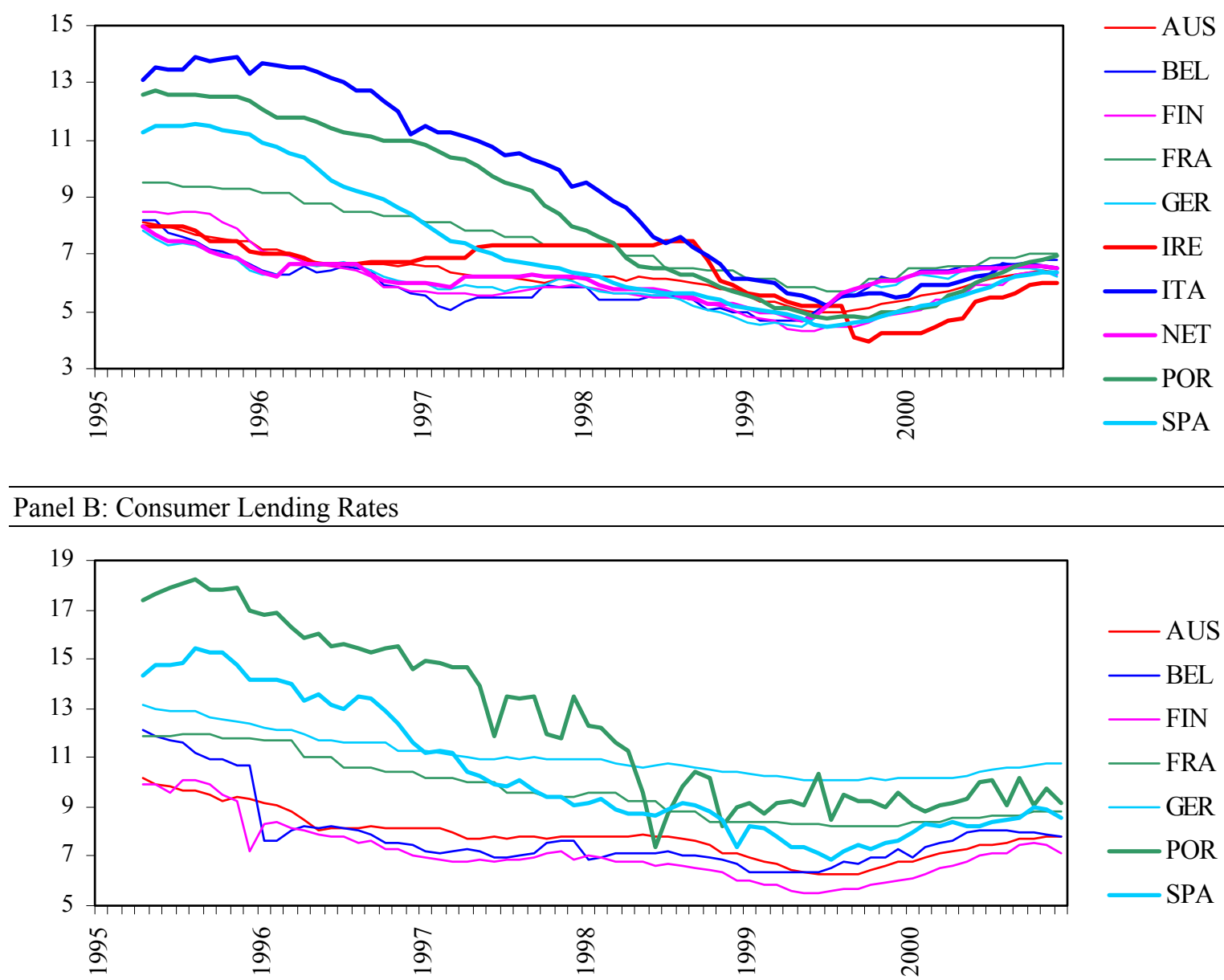

Panel C: Corporate Lending Rates

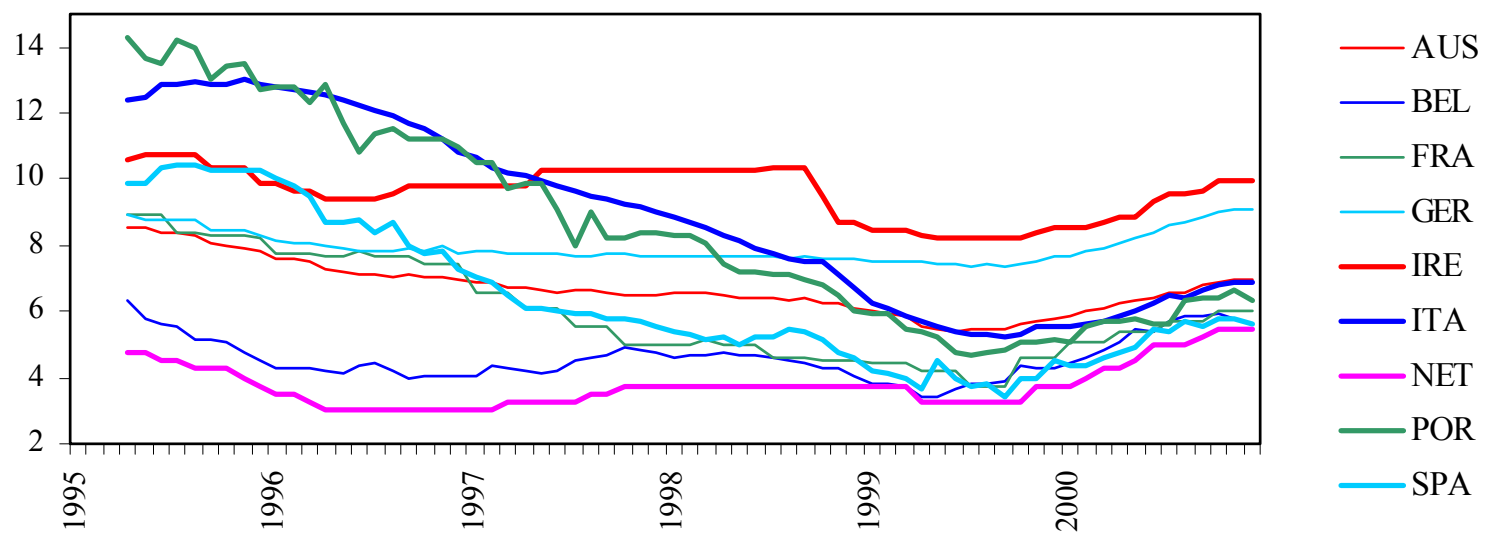


Figure 2: Real Interest Rates
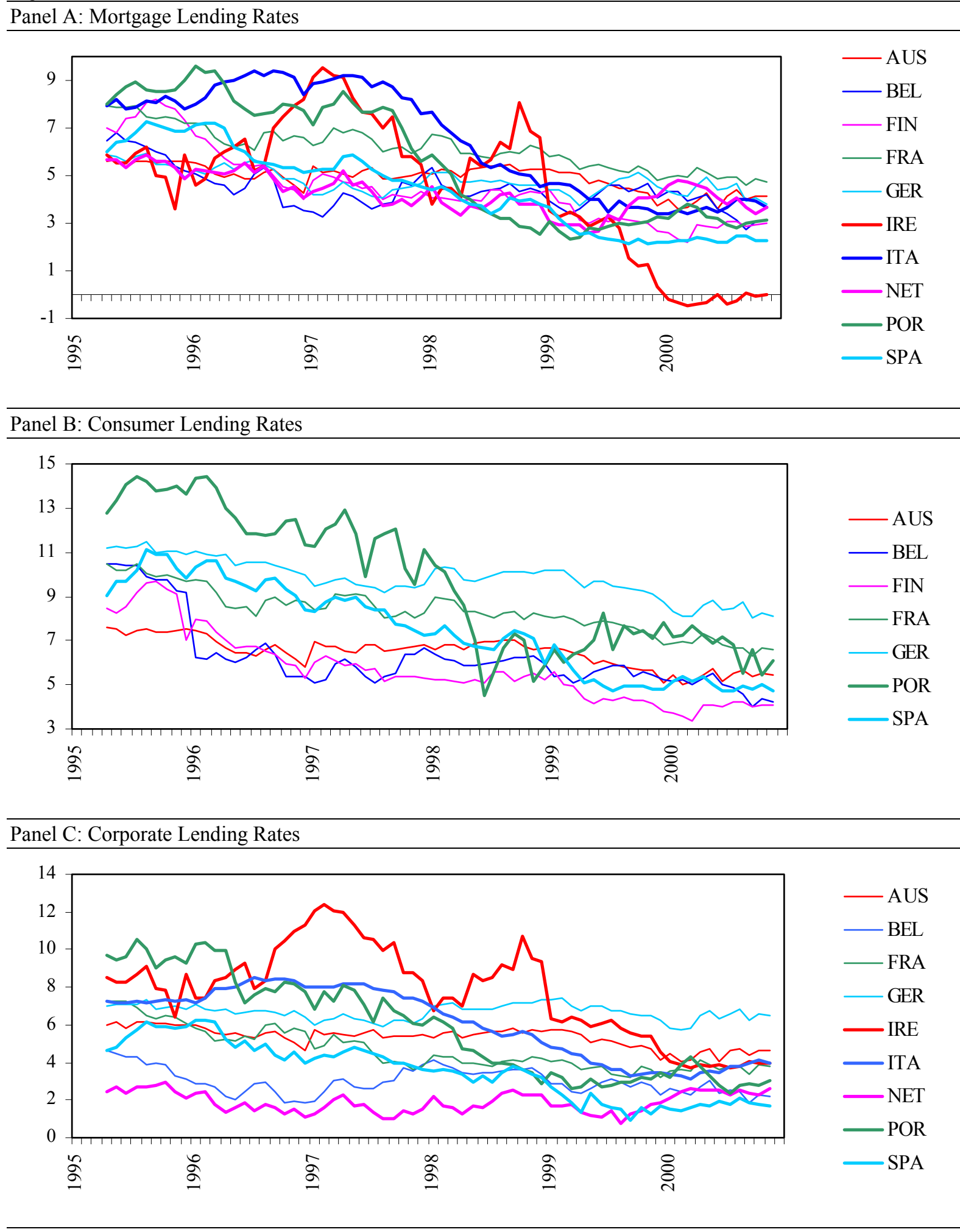
price inflation, typically and ironically leading to the highest real borrowing cost in those countries where the economy is most sluggish. Forth, for real and nominal consumer and corporate lending the cross-country differences have become smaller, but they still remain large, in particular for consumer lending rates.

\subsection{The non-applicability of the law of one price in credit markets}

While from the point of view of the Cecchini study convergence of interest rates would reflect the emergence of a single retail banking market in Euroland, we argue elsewhere (Kleimeier and Sander, 2001) that the law of one price is not the correct point of reference to make statements on the state of integration of credit markets. Typically, interest rate parity is suggested as parity for interest rates on such assets like government bonds, which are perfect substitutes under the condition of perfect capital mobility. This is clearly not the case for bank assets like loans. On the one hand, loans are characterized by heterogeneity caused by risk differences, cultural influences in bank-client relationship, country-specific strategic bank behaviour in order to cope with informational imperfections (moral hazard, incentive effects etc.), etc. Consequently, one cannot expect the law of one price to hold in the strict sense in the retail banking market. On the other hand, there is clearly not (yet) a perfect "capital" mobility that can bring about price equalization by means of cross-border arbitrage. As discussed in the previous section, banks are neither reaching out for all prospective Euroland customers, nor are consumers shopping around for credits in the whole of Euroland, nor is electronic banking yet filling the cross-border lending gap. In other words, retail banking is (still) localized. Thus, retail interest rates may not as easily equalize as suggested by the Cecchini study. To the contrary, when interest rates are equalizing in the presence of differing underlying credit characteristics this cannot even be interpreted as a 
sign of an emerging integrated banking market. Consequently, looking simply at interest rate convergence can be profoundly misleading.

We therefore propose to base the judgement on the degree of integration in the retail banking market on the existence of "co-integration" among national credit markets in Euroland (Kleimeier and Sander, 2000 and 2001). This concept realizes that although full equalization cannot be expected, market integration requires that interest rates should exhibit a certain longterm equilibrium relationship. Thus, we do not require that the national interest rate of a country $\left(\mathrm{L}_{\text {nat }}\right)$ should equal the average interest rate in the remaining Euroland $\left(\mathrm{L}_{\mathrm{EU}}\right)$ as it would be required by the "law of one price" shown in equation (1):

$$
\mathrm{L}_{\text {nat }}=\mathrm{L}_{\mathrm{EU}}
$$

Rather, we accept as a possible long-term relationship that the rates may and eventually should even differ from each other, e.g. by reflected differences in the underlying credit characteristics such that:

$$
\mathrm{L}_{\text {nat }}=\mathrm{a}+\mathrm{b} \mathrm{L}_{\mathrm{EU}}
$$

Equation (2) can be interpreted as a relationship that holds in the long-term, while in the shortterm deviations from this long-run equilibrium are possible. The existence of such a long-term relationship would reflect the existence of an integrated financial system in which "structural trends and systematic disturbances in banking cut across state borders"

\footnotetext{
${ }^{6}$ For this sentence we have used the words of Padoa-Schioppa (2000) with which he refers to the localized US financial system that is commonly viewed as integrated.
} 
Equation (2) could in principle be estimated by means of regression analysis. However, since interest rates typically follow a "random-walk", also known as an "integrated time series", one may obtain spurious results from regression analysis. To establish that there exists a certain longterm relationship one therefore has to undertake a co-integration analysis (for analytical details see Kleimeier and Sander, 2000 and 2001). If co-integration is found, this reflects that markets are integrated such that national interest rates are connected in terms of a long-term relationship as shown in equation (2). In the short-run, however, deviations from this long-run equilibrium can occur but should be corrected over time by one or more of the following three mechanisms:

- An international arbitrage process where banks increasingly shift their lending activities to countries where lending rates are the highest while consumers borrow in countries with the lowest interest rates (cross-border lending).

- When money market rates equalize by means of an international arbitrage process such changes will eventually be passed-through onto lending rates via domestic competition that ties lending and borrowing rates together (interest rate pass-through).

- Increased (international) competition, or the threat of it as suggested by the theory of contestable markets, may help to harmonize the pricing behaviour of banks and thus lead to a harmonization of retail prices.

We have investigated the presence or non-presence of such a long-term relationship among Euroland retail banking markets and inquired into these three mechanisms that eventually bind national retail interest rates together. In the following we summarize the major finding of the study. 


\subsection{Are Euroland retail banking markets already integrated?}

Our judgement on the emergence of an integrated European banking system is based on the result of the co-integration analyses that we performed for all retail lending rates for Euroland countries in both, nominal and real terms. The period of investigation is April 1995 to December 2000. We also distinguish a "pre-Euro period" characterized by the process of implementing the single market up to the end of 1998 and a second "Euro-period" that is characterized by the introduction of the single currency after 1.1.1999. While we are confident that the methodology we propose is helpful in monitoring the progress towards an integrated European banking market, the small existing database is however, a major obstacle for making to too strict judgements at the moment, for three reasons: First, there is no sufficiently harmonized data in particular on consumer credit (Diez Guardia 2000). This problem can and should be addressed in the future, but in the meantime the data provided by the ECB can be used as a first proxy. Secondly, the time period for which data for all countries are available simultaneously is very limited. And third, the introduction of the single currency has brought about structural changes that limit the available database further. In particular, by conducting a number of structural break tests we found that the introduction of the single currency in 1999 has sufficiently shaken up the structural long-term relationship. In other words, EMU has already brought about significant changes in the relation among national retail banking markets in Euroland. This evidence seems to be in line with the view that a single currency will have a major impact on the unification of a banking system. In a similar vein, Tommaso Padoa-Schioppa (2000) from the ECB board argues that the "multiplicity of currencies in the single market was a fundamental factor behind the preservation of the segmentation of the banking industry" and that "it is indeed the existence of a single currency and a single central bank which very often unifies a banking system". This, 
however, leaves our study (and any other research) in a dilemma: Either, one ignores the structural breaks and includes past data that may not anymore reflect the current state of integration. This is, of course, from a methodological point of view not acceptable. Or one bases judgements on the current state of integration only on data relating to the EMU phase. This is methodologically correct, but limits the database from which to derive judgements to two years, which obviously directly limits the power of the statistical work. We have chosen the second way, keeping in mind the limitation of the database in making judgements.

We thus tested for the existence of a long-term co-integrating relationship between national and the remaining Euroland retail banking markets (equation 2). If such a relationship can be established we speak of an integrated market. The degree of integration can then - and only then - be investigated by means of an corresponding "error-correction model" (ECM). This ECM allows us to estimate how fast the national interest rates are driven back to their long-run equilibrium relationship that they do have with the remaining average European countries. The existence and the re-approach towards such a long-term relationship after a disturbance are interpreted as evidence for the existence and degree of integration in the European retail banking market. Technically speaking, a coefficient on the error correction term is been estimated. The coefficient is typically between 0 and minus 1 , and a value e.g. of -0.2 means that 20 percent of a deviation from the long-run relationship is been corrected in every time period (here every month), while a value of -0.5 suggests that $50 \%$ of a deviation from long-run equilibrium is been corrected every time period. Clearly, the closer the coefficient is to minus 1 the faster is the adjustment process and the more integrated are the markets. 
Figure 3 illustrates our results for nominal interest rates, Figure 4 for real interest rates. Only for countries and sample or sub-sample periods where bars are shown, a co-integration relationship could be established. The absence of a bar therefore indicates that we do not find any evidence of retail market integration between this country and the remaining Euroland lending markets (countries for which data are not available are clearly indicated with an N.A.). The height of the bars then simply indicates how fast the national rates are returning to the long-term equilibrium, in other words how effective the arbitrage process works to re-establish the long-term relationship. $^{7}$

Do we then find evidence for an integrated European retail banking market? The brief answers are: No for mortgages, no for consumer lending, and may be for corporate lending. Looking into the evidence more closely we find:

1. There is evidence in favour of co-integration with respect to mortgages in nominal terms only for three countries: France, Germany and the Netherlands. Whereas co-integration can be found for all periods in France, in Germany and the Netherlands co-integration is only present for the pre-EMU period and - surprisingly - not for the EMU phase. This result is very much in line with the still localized character of mortgage lending and strengthens our earlier point that judgments about integration of retail banking markets based on interest rate convergence can be profoundly misleading. In real, inflation-corrected terms, there is some

\footnotetext{
${ }^{7}$ It should be noted, however, that in some cases despite the fact that co-integration has been accepted in the test procedures that the error-correction mechanism has not found to be statistically significant at convenient confidence levels. In such cases striped bars are being used.
} 
Figure 3: Speed of Adjustment in Co-Integration of Nominal National Interest Rates versus EU Average Panel A: Error Correction Terms for Nominal Mortgage Rates

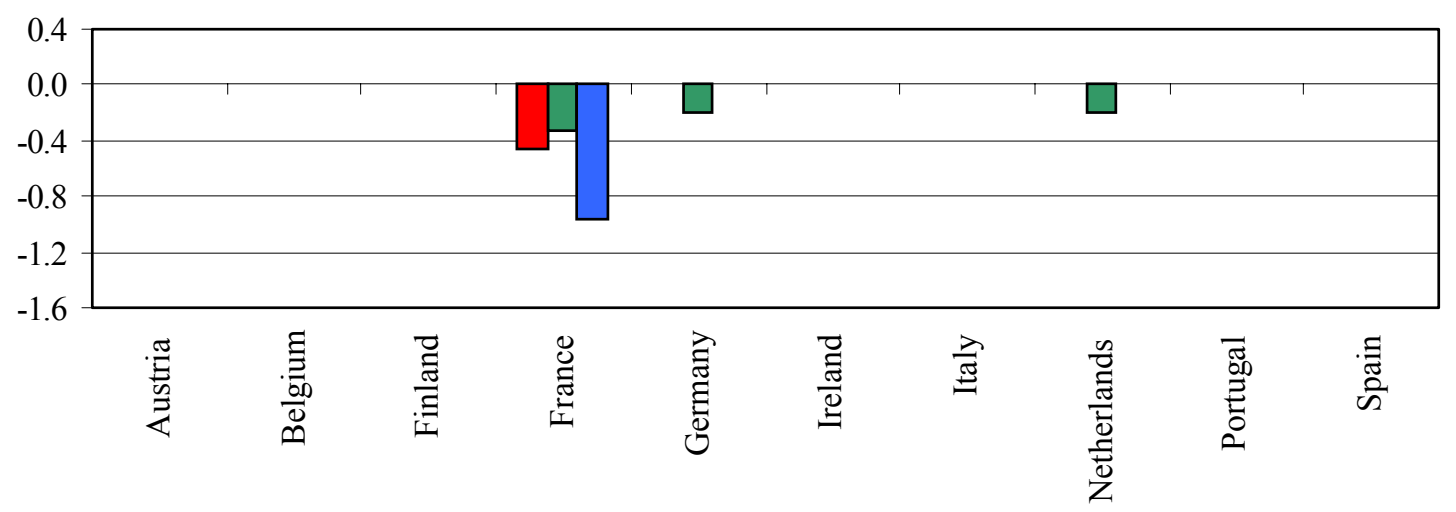

full period $\square$ pre-EMU period $\square$ EMU period

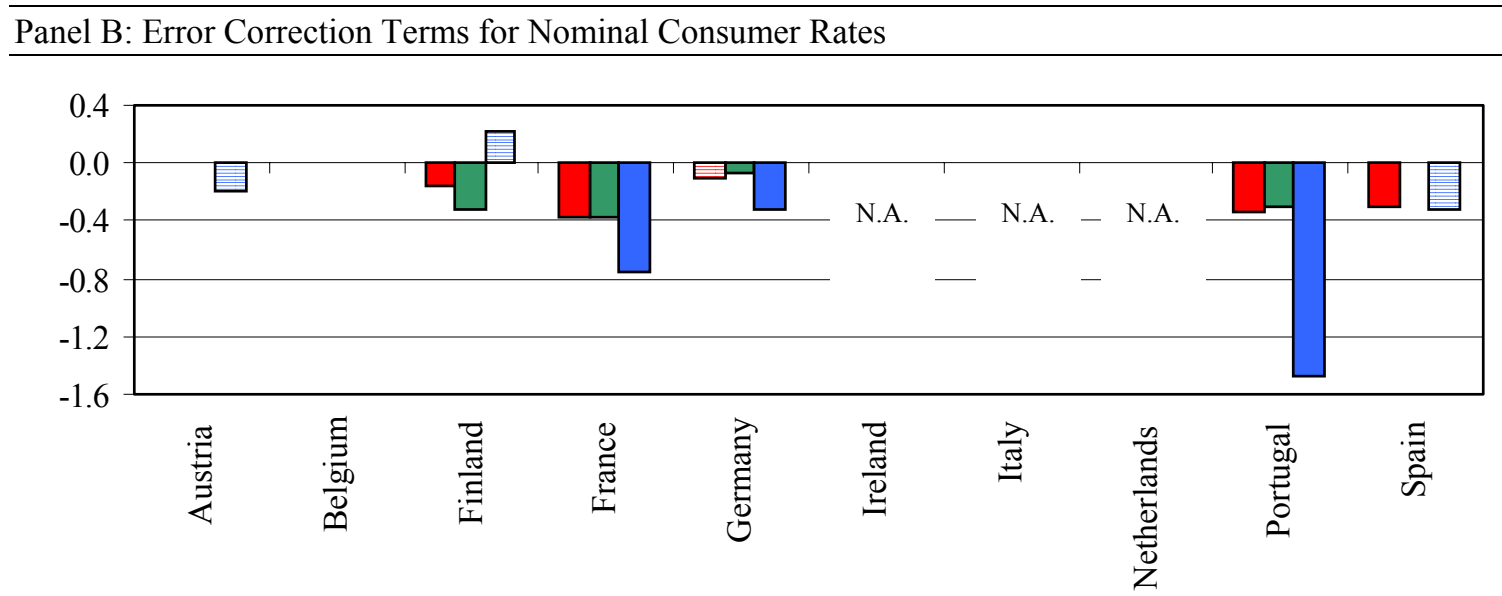

$\square$ full period $\square$ pre-EMU period $\square$ EMU period

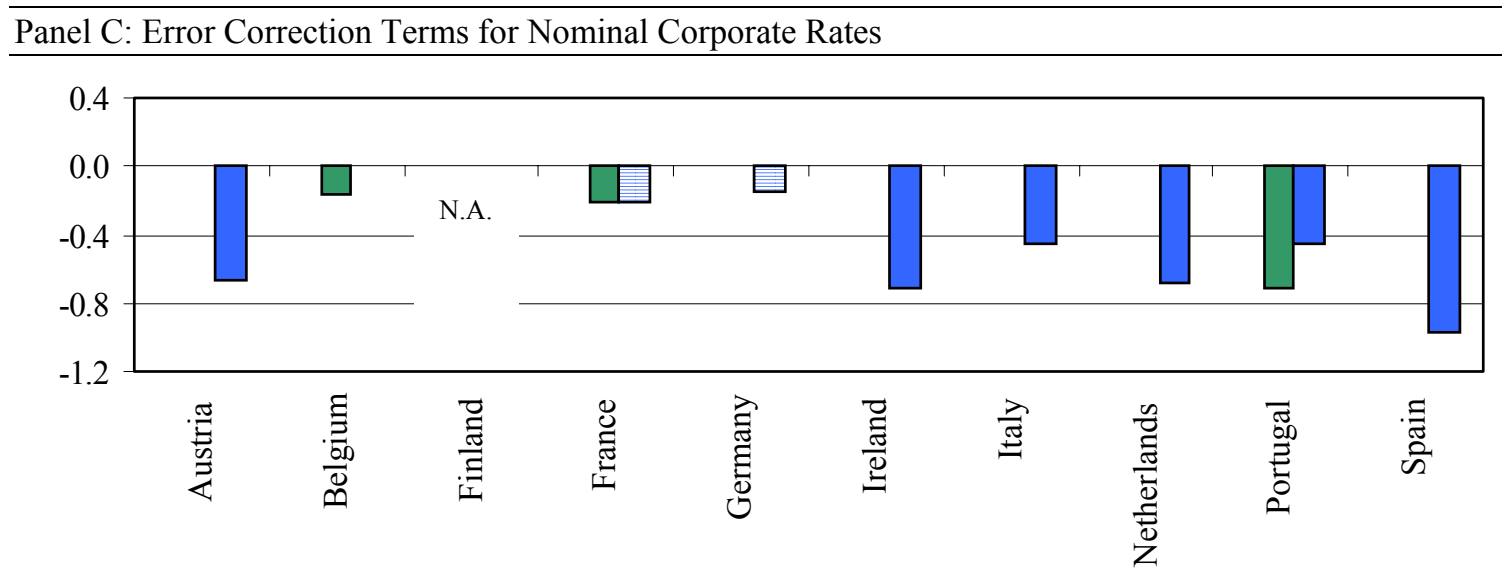

$\square$ full periou $\square$ pre-EMU period $\square$ EMU period

Note: Striped bars indicate that ECT is not significantly different from zero. N.A. $=$ not available. 
Figure 4: Speed of Adjustment in Co-Integration of Real National Interest Rates versus EU Average Panel A: Error Correction Terms for Real Mortgage Rates

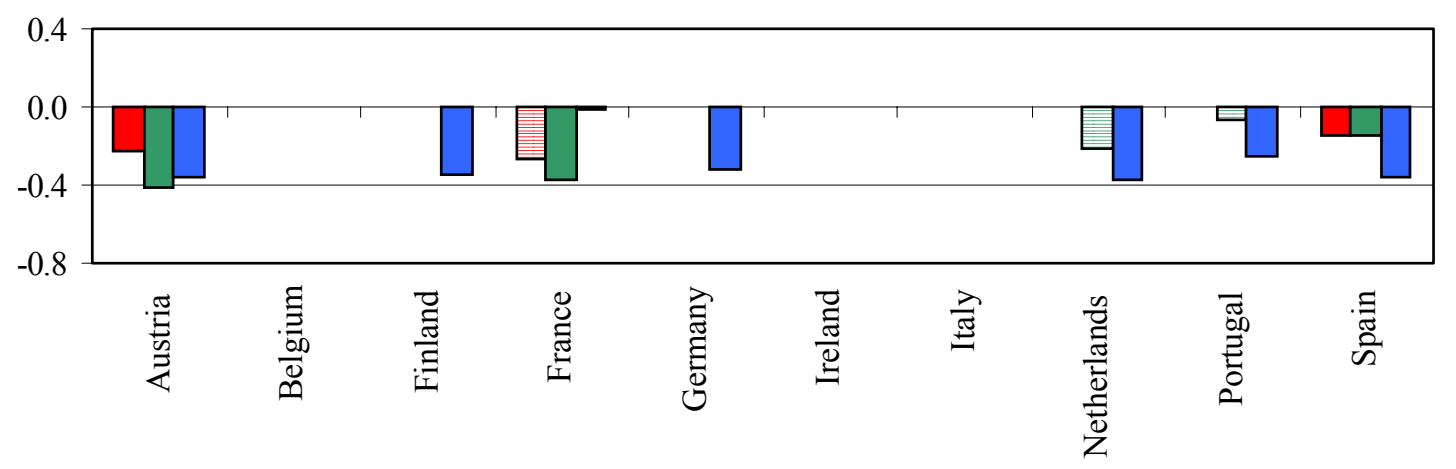

$\square$ full period $\square$ pre-EMU period $\square$ EMU period

Panel B: Error Correction Terms for Real Consumer Rates

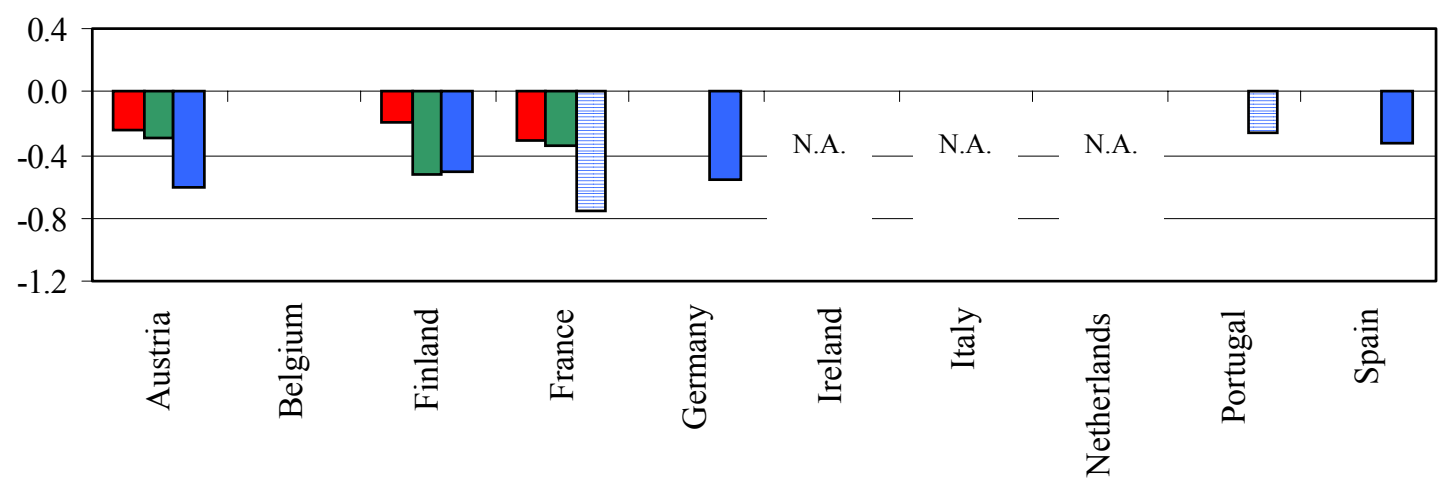

$\square$ full period $\square$ pre-EMU period $\square$ EMU period

Panel C: Error Correction Terms for Real Corporate Rates

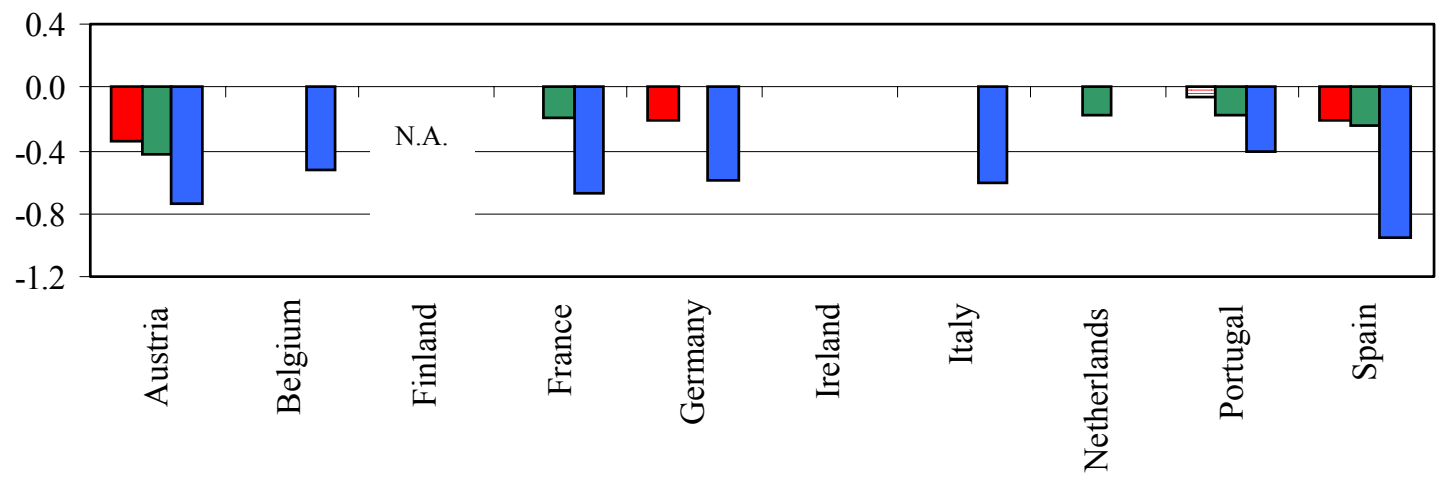

$\square$ full period $\square$ pre-EMU period $\square$ EMU period

Note: Striped bars indicate that ECT is not significantly different from zero. N.A. = not available. 
more evidence in favour of the integration hypothesis despite the fact that real mortgage rate diverge more than nominal ones because of the inflation differentials in the first two years of the EMU. The real mortgage rate results may thus reflect the fact that borrowers extensively compare prices nationally, that the national markets are more competitive and that inflation expectations play an important role in the long-term oriented mortgage market. This should, however not misread as evidence for a cross-border arbitrage process in "real mortgages". We find somewhat more, but still very limited evidence for co-integration for nominal consumer rates. For Finland, France, Germany, Portugal, and Spain we find a statistically significant adjustment process towards a long-term equilibrium relationship, however, the speed of adjustment towards this equilibrium is very low for all countries except Portugal and France in the EMU period. Also in real terms the evidence for co-integration is still very sketchy.

2. With regard to lending to the corporate sector the evidence is pointing to more cases where co-integration could be established for nominal interest rates in particular in the EMU phase, thus pointing to the more important role of competition (for example by the "threat" of direct credit finance etc.) in this sector. Specifically, for Austria, Ireland, Italy, Netherlands, Portugal, and Spain we find a significant speed of adjustment toward the long-run equilibrium relationship in the EMU period. Moreover, the speed of adjustment is higher than for consumer rates and ranges from -0.4 to -0.7 thus implying a time period of 2.5 to 1.5 months. Likewise, the strongest results in favour of integration in real borrowing costs can be found for corporate rates. Austria and Spain show significant error correction mechanisms in all periods, and France and Portugal in both sub-periods, and the results for Belgium, Germany, and Italy indicate integration in the EMU period. 
In sum, we find (almost) no evidence for an integrated banking market for mortgages. Our results for consumer lending rates are best described by a (maybe) "no". But we do find quite some evidence for integration in lending to the corporate sector in the EMU phase from nominal as well as real rate analysis. A "maybe yes" might therefore be justified, in particular in the EMU phase. Our "no, no, and may be" conclusion is, however, subject to three reservations. First, and as mentioned before our sample size is for obvious reasons very limited for the EMU period thus limiting the validity of conclusions. Second, as the effects of the single currency unfold the so far rather sketchy evidence for integration may increase. And finally, the mechanism that may eventually manifest itself in an integrated banking market may after all not be brought about by cross-border lending, mergers \& acquisitions or international arbitrage but by either interest-rate pass-through or competition on a national or even regional or local base.

\subsection{Is the transmission process efficient and symmetric?}

Rather than cross-border arbitrage, a smooth pass-through of monetary policy rate changes onto lending rates in all EMU member-countries can eventually lead to "tying together" of interest rates and "produce" the statistical artefact of evidence for or against (co-)integration. Retail interest rates could in principle follow the same time pattern if banks in the different Euroland countries would pass changes in policy-related interest rates smoothly and with the same speed onto lending rates. In other words, when there is only one money market rate in Euroland and retail markets would not appear to be integrated, this could imply differences in the way changes in money market rates are extended to the borrowers within Euroland. A limited pass-through of interest rates could also be interpreted as pointing to a still high degree of imperfect competition 
in retail banking (Cotarelli and Kouralis, 1994). And if the pass-through process is heterogeneous this could be interpreted as a limited institutional convergence process in Euroland banking (Kleimeier and Sander 2000). In our CEPS study we estimated a number of various specifications of pass-through models for all Euroland countries and both sub-periods. Without going too much into details some of the most important results are:

1. The pass-through of policy interest rates onto lending rates is less than perfect in the shortterm as well as in the long-term, in all three lending markets and in practically all Euroland countries.

2. As a rule of thumb the pass-through is in most countries the least efficient in consumer lending and the most efficient in corporate lending, thus pointing to the fact that the passthrough may at least bear some responsibility for the finding of co-integration in corporate lending.

3. Comparing across countries, the pass-through does not exhibit common characteristics. Rather it is characterized by a high degree of heterogeneity.

4. Generally, and regardless of the model specification is appears that in the EMU phase there is some evidence for a smoother pass-through (with the exception of the consumer lending market).

In sum, our results point to the fact, that the transmission process from money market interest rates to lending rates in Euroland still exhibits strong national characteristics, which are rooted in the specific features of the national finance and banking systems. While we find some evidence for the emergence of a smoother pass-through process in the recent EMU years it is still a far way from calling it a uniform banking system, in particular when speaking about consumer 
credits. These results explain at least a part of the lack of co-integration in retail banking found earlier.

\subsection{The role of national competition}

So far, we have found a limited but somewhat increasing evidence for co-integrated retail lending markets. While our first point was that arbitrage played a not so important role, the passthrough of policy rate changes onto lending rates also appeared to be imperfect. Consequently, additional regulatory efforts and pro-competition measures may be necessary to promote a smooth and more uniform pass-through of monetary policy changes. Increased competition or the threat of it as suggested by the theory of contestable markets may therefore help to harmonize the pricing behaviour of banks throughout Euroland and thus lead to a greater harmonization of retail rates.

A first insight into the degree of competition can be obtained from looking into the market structure. As discussed in section 2, most European M\&As have been national and have thus contributed to an increased national concentration in the banking sector as Tables 5 and A2 in the Annex show. Table 5 reveals that concentration is especially high in smaller countries such as Finland, the Netherlands, or Belgium where the two largest groups account for more than half of the market. In larger countries such as Germany or France the two largest groups account for clearly less than $50 \%$ of the market.

The market structure, as measured by concentration ratios, is however, only an imperfect indicator of market behaviour and market conduct. In recent years, the European banking market 
was put under pressure not only by the EU's efforts in financial market integration but also by a shift in banking activities, a trend towards disintermediation, and competition from non-bank financial firms. Whereas the core function of banks is deposit taking and lending (for details on the

Table 5: Concentration Indicators in 1998

\begin{tabular}{|c|c|c|c|c|}
\hline Country & $\begin{array}{l}\text { Share of largest } \\
\text { banking groups }\end{array}$ & $\begin{array}{r}\text { Assets } \\
\text { (in \% of total) }\end{array}$ & $\begin{array}{r}\text { Loans } \\
\text { (in \% of total) }\end{array}$ & $\begin{array}{r}\text { Deposits } \\
\text { (in \% of total) }\end{array}$ \\
\hline \multirow[t]{2}{*}{ France } & 5 largest groups & 57.2 & 71.3 & 88.2 \\
\hline & 2 largest groups & 31.6 & 40.3 & 43.9 \\
\hline \multirow[t]{2}{*}{ Germany } & 5 largest groups & 40.5 & 42.3 & 44.9 \\
\hline & 2 largest groups & 20.4 & 22.6 & 25.2 \\
\hline \multirow[t]{2}{*}{ Italy } & 5 largest groups & 41.3 & 72.3 & 56.7 \\
\hline & 2 largest groups & 23.6 & 38.4 & 31.1 \\
\hline \multirow[t]{2}{*}{ Spain } & 5 largest groups & 69.5 & 46.6 & 66.2 \\
\hline & 2 largest groups & 53.8 & 34.8 & 48.8 \\
\hline \multirow[t]{2}{*}{ Austria } & 5 largest groups & 51.5 & 65.3 & 50.5 \\
\hline & 2 largest groups & 35.6 & 46.9 & 37.2 \\
\hline \multirow[t]{2}{*}{ Belgium } & 5 largest groups & 89.7 & 98.1 & 68.0 \\
\hline & 2 largest groups & 52.0 & 58.1 & 26.3 \\
\hline \multirow[t]{2}{*}{ Finland } & 5 largest groups & 90.5 & 88.6 & 42.9 \\
\hline & 2 largest groups & 66.5 & 60.6 & 13.5 \\
\hline \multirow[t]{2}{*}{ Ireland } & 5 largest groups & 69.3 & 52.3 & 70.4 \\
\hline & 2 largest groups & 51.4 & 41.2 & 53.9 \\
\hline \multirow[t]{2}{*}{ Luxembourg } & 5 largest groups & 25.7 & 23.6 & 24.5 \\
\hline & 2 largest groups & 11.5 & 11.8 & 11.7 \\
\hline \multirow[t]{2}{*}{ Netherlands } & 5 largest groups & 63.3 & 64.3 & 92.5 \\
\hline & 2 largest groups & 51.1 & 46.1 & 69.5 \\
\hline \multirow[t]{2}{*}{ Portugal } & 5 largest groups & 78.6 & 85.7 & 93.4 \\
\hline & 2 largest groups & 47.5 & 54.3 & 66.3 \\
\hline
\end{tabular}

Source: Belaisch et.al. (2001), Table 9.

theory of financial intermediation see Diamond 1984 and Bhattacharya and Thakor 1993), European banks have long tended towards universal banking activities. Consequently, the banking activities allowable under European law reflect this universal nature of the European bank and includes next to deposit taking, lending, financial leasing, money transmission, payment services, guarantee provision also investment activities such as trading for own account or for customer, participation in shares issues, corporate advice, arrangement of mergers and acquisitions, money brokering, 
portfolio management and advice, safekeeping of securities, and offering credit reference services, safe custody services (Zimmerman, 1995). Among these activities banks have more recently shifted their focus away from interest-generating activities such as deposit taking and lending towards feegenerating services such as investment banking. As Belaisch et.al. (2001) report, in the Euroland on average 22 percent of banks' operating income in 1998 came from commissions compared to only $16 \%$ in 1992. One reason for this shift were falling net interest margins (NIM). Between 1992 to 1998 NIM have declined from 2 to 1.5 percent of banks assets. Belaisch et. al. (2001) interpret that as the result of increased competition, which makes the traditional lending activities less attractive for banks and drives them into more profitable fee-generating activities. According to Davis (1999), this shift was furthermore driven by factors including deregulation, advances in technology, the growth of institutional investors and the growth of securities markets. The growth in securities markets for examples encouraged corporate disintermediation whereas financial liberalisation increased non-bank competition from insurance companies or non-financial competition from department stores of car manufacturers.

As the above discussion reveals, there is a trend toward decreasing NIMs. In order to validate this development in the retail market we have calculated the interest rate spreads - that is, the difference between the lending rate and the money market rate ${ }^{8}$. Figure 3 shows the results. With few exemptions spreads have fallen and the differences across countries have become smaller. However, it is a well-known fact that spreads are lower when interest rates are low. Thus, a part of this development can be contributed to macroeconomic developments. Moreover, consumer lending

\footnotetext{
${ }^{8}$ De Bondt (1998) argues that interest rate spreads can be used as a rough indicator of imperfect competition. He uses a measure of spreads defined as the difference between lending and deposit rates, which can also be seen as the opportunity cost of intermediation.
} 
rates have the least profited from these developments with spreads ranging from an average of 6.2 percent in Germany to 2.7 percent in Finland under the single currency regime. In the more competitive corporate lending market spreads are mostly below 2 percent with notable exemptions of Germany and Ireland whereas for mortgages the spreads are ranging between 2.7 percent (France) and 1.4 percent (Ireland). These observations are in line with our earlier findings in the cointegration analysis: The more competitive credit markets are, the smoother is the pass-through of interest rates and the more likely is a homogenous behaviour of credit market across Euroland. In other words, creating a single European banking market cannot only rely on the Europe-wide deregulation and facilitation of cross-border activities. Rather, in the context of localized lending activities promoting and securing a competitive environment at the regional or even local level remains essential. 
Figure 3: Interest Rate Spreads

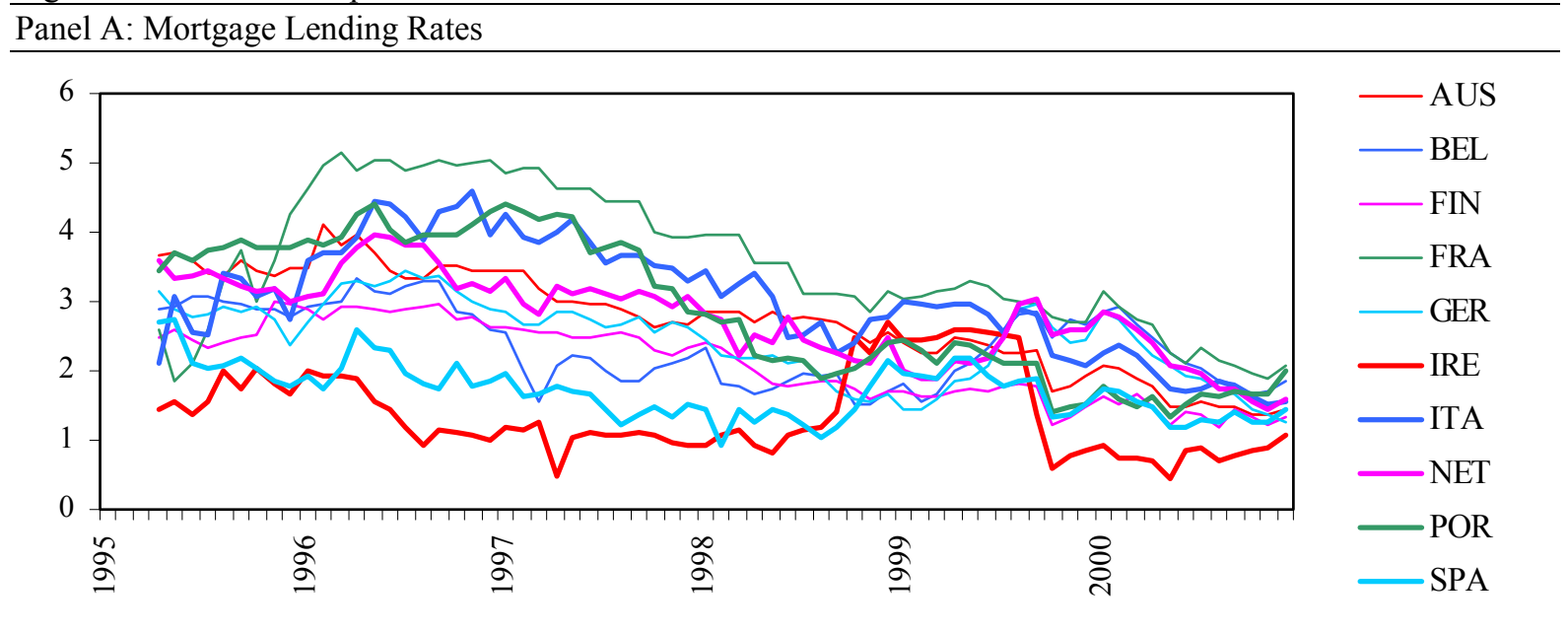

Panel B: Consumer Lending Rates
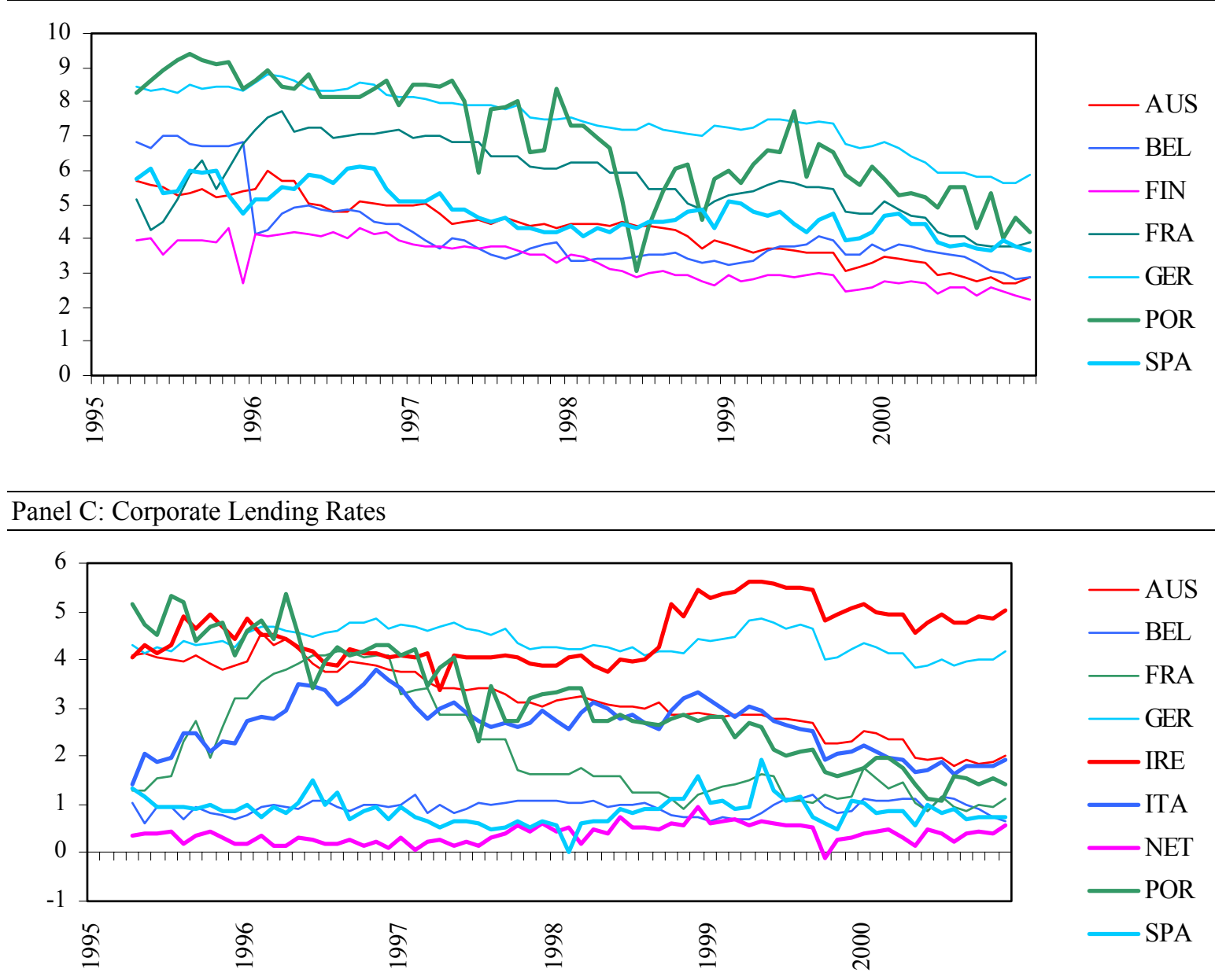


\section{Conclusions}

Our study reviews the process towards creating a single European retail banking market. The EU has aimed at integrating the traditionally heterogeneous banking market in Europe by means of harmonizing legislation. While the wholesale banking market integration is considered to be more advanced, retail banking integration is still in its infancy. Cross-border lending, crossborder mergers, and the promises of new technologies have not yet delivered the creation of a single retail banking market. In this paper we provide new evidence on this issue. In particular, we find that there are some tendencies for a more integrated corporate lending market, while consumer lending markets are still remain more fragmented. We identify three reasons for a lack of integration: A lack of international arbitrage, a limited pass-through of interest rate changes onto lending rates, and a limited national and international competitive retail banking environment. Regarding the first point, lending is still a very much localised activity and may eventually remain to be so. If, however, cross-border lending is limited this lack of internationalisation of lending could have been healed by a competitive behaviour of loan pricing. In such a case, the changes in the bank's cost of funds would be fully passed onto the borrowers. Our study finds that also in this respect consumer credit lending is lagging behind its corporate lending cousin, explaining the lack of integration in Euroland consumer credit markets. Finally, however, our empirical work finds first signs that a closer integration is becoming visible after the introduction of the single currency. 


\section{References}

Belaisch, A., L. Kodres, J. Levy and A. Ubide, 2001, Euro-area banking at crossroads, International Montary Fund, Working paper WP/01/28.

Berger, A.N., R. S. Demsetz, and P.E. Strahan, 1999, The consolidation of the financial services industry: Causes, consequences, and implication for the future, Journal of Banking and Finance 23 (2), 135-194.

Bhattacharya, S. and A.V. Thakor, 1993, Contemporary Banking Theory, Journal of Financial Intermediation (3), 2-50.

Bredemeier, S., 1995, Integration within the banking sector, in: Lang, F.P. and Ohr, R. (eds) International Economic Integration, Heidelberg: Physica Verlag, 159-180.

Commission of the European Communities, 1988, European economy: The economics of 1992, no 35, March, Brussels: Commission of the European Communities.

Commission of the European Union, 1998, Financial Services: Building a framework for action, Communication of the Commission, COM(1998)625, 28.10.1998.

Commission of the European Union, 1999, Financial services: Implementing the framework for financial markets: Action plan, Communication of the Commission, COM(14999)232, 11.05.99.

Cotarelli, C. and A. Kourelis, 1994, Financial structure, bank lending rates, and the transmission mechanism of monetary policy, IMF Staff Papers 41, No.4.

Davis, E.P., 1999, EMU and the evolution of financial structure, Financial Market Trends, No. 72, February, 39-56.

De Bondt, G., 1998, Financial structure: Theories and stylised facts for six EU countries', De Economist 146 (2), 271-300. 
Diamond, D.W., 1984, Financial intermediation and delegated monitoring, Review of Economic Studies, 393-414.

Diez-Guardia, N., 2000, ECRI Research Report No.1: Consumer credit in the EU, European Credit Research Institute, Brussels.

European Central Bank, 1999a, Possible effects of EMU on the EU banking system in the medium and long term, February.

European Central Bank, 1999b, Banking in the euro area: Structural features and trends, ECB Monthly Bulletin April, 41-53.

European Central Bank, 1999c, The effects of technology on the EU banking systems, July.

European Central Bank, 2000a, The euro area one year after the introduction of the euro: Key characteristics and changes in the financial structure, ECB Monthly Bulletin January, 3549.

European Central Bank, 2000b, EMU and banking supervision, ECB Monthly Bulletin April, 4964.

Kleimeier, S., 2001, Banking in western Europe, forthcoming in Malcom Warner (ed.), The International Encyclopaedia of Business and Management, $2^{\text {st }}$ edition, International Thomson Business Press.

Kleimeier, S. and H. Sander, 2001, Consumer credit rates in the Eurozone - Evidence no the emergence of a single Eurozone retail banking market, research report prepared for the European Credit Research Institute of the Centre of European Policy Studies, Brussels.

Kleimeier, S. and H. Sander, 2000, Regionalisation versus globalisation in European financial market integration: Evidence from co-integration analysis, Journal of Banking and Finance 24 (6), 1005-1043. 
Marois, B., 1997, French banks and European strategy, European Management Journal 15 (2), 183-189.

Molyneux, P., 1996, Banking in western Europe, in: Malcom Warner (ed.), The International Encyclopaedia of Business and Management, $1^{\text {st }}$ edition, International Thomson Business Press.

Padoa-Schioppa, T., 2000, Is a euroland banking system already emerging?, Lecture at the Société Universitaire Européenne de Recherches Financières, Vienna 29 April, European Central Bank (www.ecb.int/key/00/sp000429.htm).

Tourani Rad, A. and L. van Beek, 1999, Market valuation of European bank mergers, European Management Journal 17 (5), 532-540.

Zimmerman, G.C., 1995, Implementing the single banking market in Europe, Federal Reserve Bank of San Francisco Economic Review 3, 35-51. 


\section{Annex}

Table A1. Recent Mergers and Acquisitions Among Large Banking Groups

\begin{tabular}{|c|c|}
\hline Panel A: Domestic Merger & \\
\hline Country & Post-Merger Bank (Pre-Merger Banks) \\
\hline Spain & BSCH (Banco Santander + Banco Central Hispano + Banesto) \\
\hline & BBVA (Banco Bilbao Vizcaya + Argentaria) \\
\hline Austria & Bank Austria (Bank Austria + Creditanstalt) \\
\hline & Erste Bank (Giro Credit + Erste SparCasse) \\
\hline Italy & SanPaolo IMI (Instituto Bancario SanPaolo di Torino + IMI) \\
\hline & Banca Intesa (Banco Ambrosiano Veneto + Cariplo $+\mathrm{CPP})+\mathrm{BCI}$ \\
\hline & Unicredito ItaIiano (Credito Italiano + Unicredito) \\
\hline Germany & HypoVereinsbank (Bayerische Vereinsbank + HypoBank) \\
\hline & Deutsche Bank + Bankers Trust \\
\hline France & BNP-Paribas (BNP + Paribas) \\
\hline & Banques Populaires + Natexis \\
\hline & Credit Mutuel + CIC \\
\hline & Caisse d'Epargne + Credit Foncier \\
\hline & Societe Generale + Credit du Nord \\
\hline & Credit Agricole + Banque Sofmco + Banque Indosuez \\
\hline Portugal & Banco Comercial Portugues + Banco Portugues do Atlantico \\
\hline & Caixa Geral de Depositos + Banco Pinto \& Sotto Mayor \\
\hline Belgium & KBC (Kredietbank + Cera) \\
\hline & Bacob + Artesia Bank \\
\hline Netherlands & ABN-Amro (ABN + Amro) \\
\hline Denmark & Unibank (Unibank + Tryg-Baltica) \\
\hline Panel B: Cross-Border Me & gers and Alliances \\
\hline Mergers & $\begin{array}{l}\text { Dexia (Credit Local de France and Credit Communal de Belgique) } \\
\text { Fords (Generale de Bank and ASLK-CGER Bank) } \\
\text { Merita-Nordbanken-Unidanmark } \\
\text { ING + Banque Brussels Lambert } \\
\text { BSCH + Totta \& Acores } \\
\text { HSBC + CCF } \\
\text { Bank Austria + Hypovereinsbank }\end{array}$ \\
\hline Alliances/minority stakes & $\begin{array}{l}\text { BSCH-Royal Bank of Scotland-SanPaoloIMI-SG-Commerzbank-- } \\
\text { Champalimaud } \\
\text { Credit Agricole-Credit Lyonnais-Banca Intesa } \\
\text { BBVA-Banco di Napoli-BNL-Credit Lyonnais } \\
\text { ABN-Amro - Banca di Roma }\end{array}$ \\
\hline
\end{tabular}

Source: Belaisch et.al. (2001), Table 7. 
Table A2: The Top 30 Euro Area Banking Groups

\begin{tabular}{|c|c|c|c|c|c|c|}
\hline \multicolumn{2}{|c|}{ Total Assets in US\$ million in 1990} & \multicolumn{2}{|c|}{ Total Assets in US\$ million in 1995} & \multicolumn{3}{|c|}{ Total Assets in US\$ million in 1999} \\
\hline Credit Agricole & 241992 & Deutsche Bank & 368261 & Deutsche Bank + Bankers Trust* & & 732534 \\
\hline $\mathrm{BNP}$ & 231463 & Credit Agricole & 328152 & BNP Paribas* & & 688361 \\
\hline Credit Lyonnais & 210727 & Cr6dit Lyonnais & 327903 & ABN-AMRO & & 504122 \\
\hline Deutsche Bank & 202263 & ABN-Amro & 290835 & Hypovereinsbank* & & 504122 \\
\hline Soci6te Gnerale & 164741 & Societe Generale & 278006 & Credit Agricole + Indozuez* & & 455792 \\
\hline Caisses d'Epargne & 152722 & BNP & 271635 & Societe Generale & & 447545 \\
\hline Dresdner Bank & 147001 & Dresdner Bank & 253818 & Dresdner Bank & & 427261 \\
\hline Paribas & 138668 & Paribas & 242219 & Westdeutsche Land Giro & & 408372 \\
\hline Commerzbank & 112825 & Westdeutsche Land Giro & 237535 & Commerzbank & & 381359 \\
\hline DG Bank & 109168 & Commerzbank & 220704 & ING Bank Group* & & 326813 \\
\hline IBSan Paolo & 107403 & Bayerische Vereinsbank & 204423 & Fortis* & & 323567 \\
\hline Westdeutsche Landesbank Giro & 104508 & Caisses d'Epargne & 187411 & Rabobank Netherlands & & 291353 \\
\hline Bayeriscbe Vereinsbank & 102191 & Bayerische Hypotheken \& Wechsel Bank & 177540 & Credit Mutuel + CIC* & & 284461 \\
\hline BNL & 100967 & Bayerische Landesbank & 171816 & Bayerische Landesbank & & 284064 \\
\hline Amro Bank & 93824 & Krediteanstalt fur Wiederaufbau & 158736 & $\mathrm{BSCH}^{*}$ & & 258872 \\
\hline Bayerische Landesbank & 90855 & DG Bank & 158227 & DG bank & & 248297 \\
\hline $\mathrm{ABN}$ & 90411 & Bankgesellschaft Berlin & 157197 & Credit Lyonnais & & 243708 \\
\hline Bayerische Hypotheken \& Wechsel Bank & 90129 & Rabobank Netherlands & 155082 & Banques Populaires + Natexis* & & 239673 \\
\hline Rabobank Netherlands & 90016 & San Paolo Bank Holding & 153115 & BBVA* & & 237747 \\
\hline $\mathrm{BCI}$ & 88594 & Generale Bank & 126889 & Caisses d'Epargne & & 235660 \\
\hline NMB Postbank Group & 84194 & International Nederland Bank & 125343 & Dexia* & & 232601 \\
\hline Cariplo & 82103 & Norddeutsche Landesbank & 118507 & Bankgesellschaft Berlin & & 220646 \\
\hline Monte dei Pascbi di Siena & 75694 & Banco Santander & 114174 & SanPaolo IMI* & & 185403 \\
\hline Credito Italiano & 75223 & Cariplo & 107788 & Banca Intesa* & & 179258 \\
\hline CIC Group & 74725 & Sudwest LB & 107602 & Unicredito Italiano* & & 171730 \\
\hline BBV & 69986 & Cr6dit Communal de Belgique & 99941 & Norddeutsche Land Giro & & 170759 \\
\hline Generale Bank & 67637 & BBV & 99174 & KBC Bank* & & 163125 \\
\hline Nordeutsehe Landesbank & 67515 & BNL & 98662 & Bank Austria* & & 140161 \\
\hline Banques Populaires & 64701 & $\mathrm{CIC}$ & 97839 & $\mathrm{BCI}$ & & 132188 \\
\hline Banque Indosuez & 55316 & Banca di Roma & 93373 & Banca di Roma & & 122145 \\
\hline \multirow[t]{2}{*}{$\mathrm{BBL}$} & 50548 & $\mathrm{BCI}$ & 92449 & Merita Nordbanken* & & 112049 \\
\hline & \$ mio & $\$ \mathrm{n}$ & change & & $\$$ mio & change \\
\hline Average & 114905 & 1907 & $+66 \%$ & & 320977 & $+68 \%$ \\
\hline Average tp five & 210237 & 3186 & $+52 \%$ & & 576986 & $+81 \%$ \\
\hline Average top three & 228061 & 3414 & $+50 \%$ & & 641672 & $+88 \%$ \\
\hline
\end{tabular}

Source: Belaisch et.al. (2001), Table 8. * Banking groups are the result of recent mergers. 